\title{
PENGEMBANGAN BUKU KOMIK FISIKA POKOK BAHASAN NEWTON BERBASIS KONSTRUKTIVISME UNTUK MENINGKATKAN MOTIVASI BELAJAR SISWA
}

\author{
Farida Huriawati $^{1)}$, Purwandari ${ }^{1,2)}$, Intan Permatasari ${ }^{1,3)}$ \\ ${ }^{1,2,3}$ Program Studi Pendidikan Fisika, FPMIPA \\ IKIP PGRI MADIUN \\ Email: frd21pfisae@gmail.com
}

\begin{abstract}
Abstrak
Penelitian ini bertujuan: (1) Menghasilkan sebuah buku komik fisika berbasis konstruktivisme sebagai media pembelajaran fisika siswa kelas VIII SMPN 1 Kecamatan Sampung; (2) Mengetahui kualitas buku komik fisika berbasis konstruktivisme pada pokok bahasan hukum newton berdasarkan hasil penilaian validator dan respon siswa; (3) Mengetahui persentase peningkatan motivasi belajar siswa setelah menggunakan media pengembangan buku komik fisika berbasis konstruktivisme. Model pengembangan yang digunakan untuk mengembangkan media pembelajaran IPA fisika berbasis konstruktivisme adalah adaptasi model pengembangan prosedural menurut sugiyono dan model pengembangan 4-D oleh S. Tiagarajan Dorothy S. Semmel dan Melvyn L. Semmel. Desain uji coba produk pengembangan dalam penelitian ini yaitu uji perorangan, uji kelas kecil, dan uji coba terbatas. Subjek uji coba adalah 6 siswa untuk uji kelas kecil dari kelas VIII B SMPN 1 Kecamatan Sampung dan uji coba terbatas yaitu 24 siswa kelas VIII D SMPN 1 Kecamatan Sampung. Hasil penelitian menunjukkan bahwa: 1) Langkah-langkah pembuatan buku komik fisika dalam penelitian ini yaitu analisis ujung depan, analisis siswa, analisis materi, menentukan format, perancangan, validasi ahli, uji kelas kecil dan uji coba; 2) Kualitas buku komik fisika berbasis konstruktivisme ini memperoleh kategori baik dimana yang telah dinilai oleh ahli materi memperoleh presentase sebesar 88,44\% (sangat layak) dan ahli media memperoleh presentase sebesar 91,11\% (sangat layak) sedangkan pada kelas kecil memperoleh presentase sebesar 97,78\% (sangat baik) dan uji coba terbatas memperoleh presentase sebesar 92,48\% (sangat baik); 3) Hasil motivasi belajar siswa dilakukan uji kelas kecil memperlihatkan peningkatan tinggi dengan rata-rata $\mathrm{N}$-Gain sebesar 0,70 dan pada uji coba terbatas memperlihatkan peningkatan sedang dengan rata-rata $\mathrm{N}-$ Gain sebesar 0,67.
\end{abstract}

Kata Kunci: Buku Komik Fisika, Konstruktivisme, Motivasi Belajar

\section{PENDAHULUAN}

Ilmu pengetahuan dan teknologi mengalami perkembangan dari tahun ke tahun, seiring dengan perkembangan zaman. Perkembangan ilmu pengetahuan dan teknologi semakin mendorong upaya-upaya pembaruan dalam pemanfaatan hasil-hasil tekonogi dalam proses belajar (Arsyad Azhar, 2014: 2).

Dalam proses belajar mengajar siswa sering dihadapkan pada materi pembelajaran yang di luar pengalaman siswa, hal tersebut menyebabkan proses pembelajaran yang sedang berlangsung tidak berjalan secara efektif. Oleh karena itu media pembelajaran menjadi salah satu komponen penting dalam sistem pembelajaran sebagai alat perantara informasi. Salah satunya dalam pembelajaran IPA khususnya fisika. Dalam Pembelajaran IPA khususnya fisika seringkali membuat siswa merasa jenuh dalam mempelajarinya, rasa jenuh siswa muncul karena tidak ada motivasi yang dilakukan oleh guru pada saat proses pembelajaran berlangsung. Guru sekurangkurangnya dapat menggunakan alat yang murah dan efisien yang meskipun sederhana dan bersahaja, tetapi merupakan keharusan dalam upaya mencapai tujuan pengajaran yang dicapai (Arsyad Azhar, 2014: 2).

Berdasarkan hasil observasi dan pengamatan di SMPN 1 Kecamatan Sampung diperoleh fakta bahwa salah satu guru fisika 
kurang memanfaatkan penggunaan media dalam pembelajaran khususnya dalam mata pelajaran fisika. Pernyataan tersebut dibuktikan dengan media yang digunakan di sekolah tersebut terdiri atas papan tulis, LKS, dan buku paket. Persamaan matematis yang begitu rumit dan fenomena fisika begitu banyak yang masih bersifat abstrak, sehingga siswa merasa jenuh dan malas ketika dihadapkan pada mata pelajaran fisika.

Banyak penelitian yang menggagas alternatif baru dalam mempelajari fisika dari pengembangan model, media, hingga bahan ajar. Semua terus dilakukan demi kemajuan pembelajaran. Salah satu pengembangan yang populer adalah media grafis. Media grafis merupakan suatu penyajian secara visual menggunakan titik-titik, garis-garis, gambargambar, tulisan-tulisan, atau simbol visual yang lain dengan maksud untuk mengihtisarkan, menggambarkan, dan merangkum suatu ide data atau kejadian (Daryanto, 2010:19). Media grafis akan coba diaplikasikan dalam pengembangan media pembelajaran fisika yaitu dalam bentuk buku komik fisika berbasis konstruktivisme. Buku komik fisika berbasis konstruktivisme ini bertujuan untuk menjadikan pembelajaran fisika menjadi lebih menyenangkan dan efektif. Bentuk dari buku komik fisika berbasis konstruktivisme sendiri adalah sebuah buku komik yang menyediakan cerita sederhana dan mudah dipahami, untuk memudahkan siswa dalam menguatkan konsep hukum newton seperti; pengertian gaya, gaya gravitasi, gaya gesek, hukum newton 1 , hukum newton 2 dan hukum newton 3.

\section{METODE PENELITIAN}

Metode penelitian yang digunakan adalah metode penelitian dan pengembangan (Research and Development). Penelitian dan pengembangan media praktikum gerak harmonik menggunakan osilator digital detector mengacu pada model $4 D$ yang dikemukakan oleh Thiagarajan, dkk. (1974). Model pengembangan 4D (four-D models) terdiri atas 4 tahap yaitu tahap pendefinisian (define), tahap perencanaan (design), tahap pengembangan (develop), dan tahap penyebaran (disseminate). Penelitian pengembangan media praktikum gerak harmonik akan dilakukan di kelas VIII B SMPN 1 Kecamatan Sampung selama 6 bulan pada semester genap tahun ajaran 2015/2016. Pemilihan tempat ini didasarkan pada hasil observasi yang telah dilakukan. 


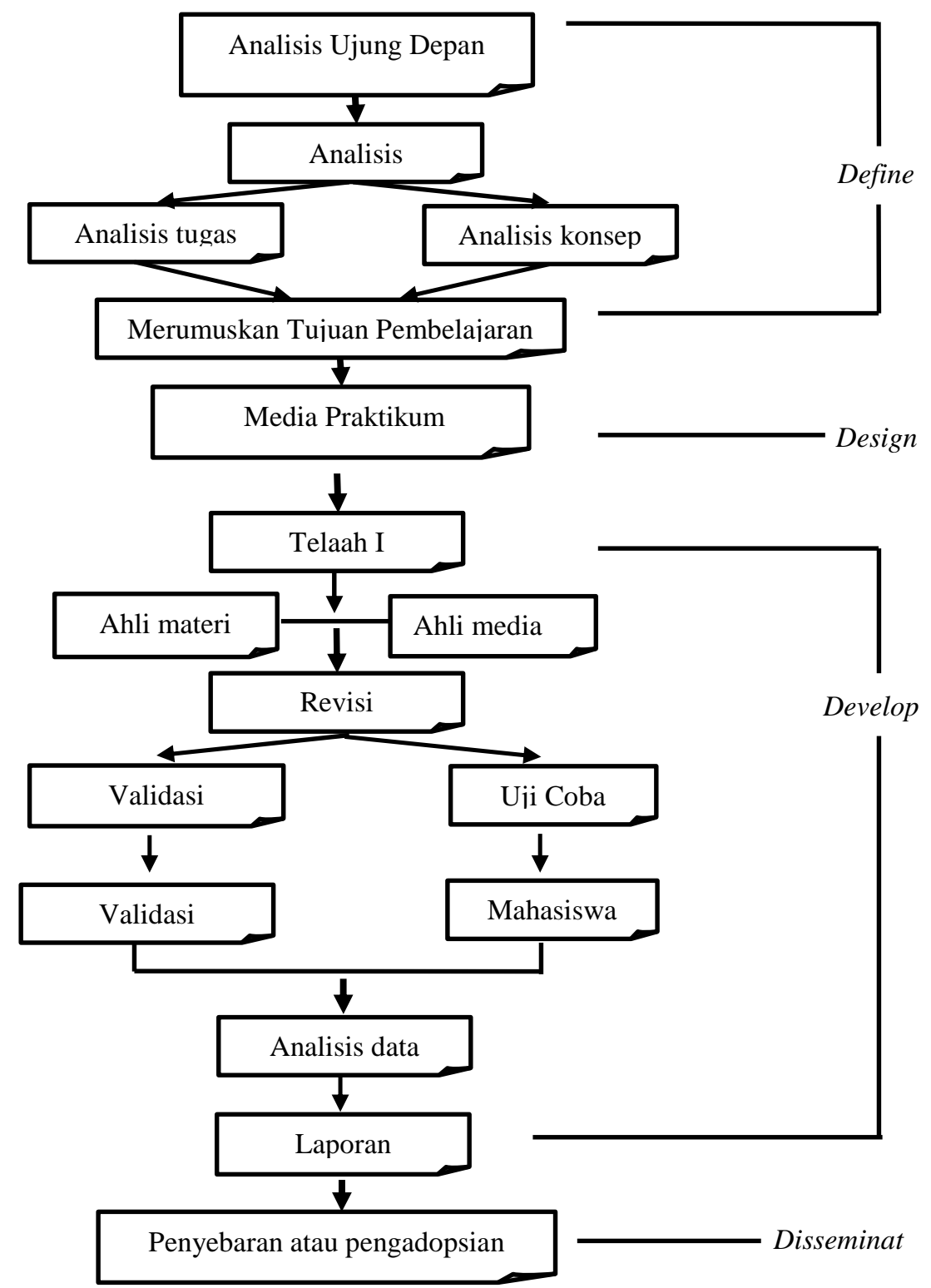

Gambar 1. Rancangan Pengembangan Media Praktikum Gerak Harmonik (Thiagarajan, dkk., 1974 dalam Sugiyono, 2010)

\section{HASIL DAN PEMBAHASAN}

Penelitian sesuai dengan model pengembangan yang terdiri atas 4 tahap yaitu tahap pendefinisian (define), tahap perencanaan (design), tahap pengembangan (develop), dan tahap penyebaran (disseminate).

\section{a. Tahap Pendefinisian (Define)}

a. Analisis ujung depan

Berdasarkan hasil wawancara kepada guru, maka diperoleh data berupa masalah dasar yang dihadapi siswa dalam pembelajaran adalah sebagai berikut: 1) Siswa mengalami kesulitan dalam memahami konsep, 2) Siswa kesulitan dalam hitungan matematis dan penerapan ilmu pengetahuan khususnya fisika yang mereka pelajari di kelas dengan kehidupan nyata siswa atau yang pernah siswa alami, 3) Kurangnya pemanfaatan dalam menggunakan media pada saat proses pembelajaran fisika, 4) Siswa tidak memiliki motivasi ketika mempelajari fisika karena sudah dianggap sulit.

b. Analisis Siswa

Untuk mengetahui kesulitan apa saja yang dihadapi siswa ketika pembelajaran fisika berlangsung, maka dilakukan wawancara secara tertulis dengan seluruh siswa kelas VIII D SMPN 1 Kecamatan Sampung yang berjumlah 22 orang siswa. Sebagian 
besar siswa menganggap fisika sangat sulit karena banyak rumus yang harus dihafalkan sehingga mereka tidak bisa memahami materi yang sedang diajarkan oleh guru karena, guru kurang memanfaatkan media dalam proses belajar mengajar sehingga motivasi belajar siswa tergolong rendah. Subjek penelitian adalah siswa kelas VIII D SMPN 1 Kecamatan Sampung.

c. Analisis Konsep

Materi pembelajaran fisika pada kelas VIII semester I yang telah dipelajari adalah gerak pada makhluk hidup dan benda,dan sub bab yang dibahas adalah hukum newton berdasarkan RPP yang mengacu pada silabus yang telah ditetapkan oleh kurikulum. Kompetensi Dasar (KD) pada sub bab hukum newton yaitu memahami gerak lurus dan pengaruh gaya terhadap gerak berdasarkan hukum newton, serta penerapannya pada gerak makhluk hidup dan gerak benda dalam kehidupan sehari-hari serta melakukan penyelidikan tentang gerak, gerak pada makhluk hidup, dan percobaan tentang pengaruh gaya terhadap gerak. Materi tersebut juga didominasi oleh materi yang sering ditemui dalam kehidupan sehari-hari.

d. Perumusan Tujuan

Dalam

penyusunan

pengembangan media diperlukan suatu analisis tujuan yang akan dicapai. indikator pencapaian kompetensi :

1. Menganalisis peristiwa kelembaman pada benda didalam buku komik fisika.

2. Menganalisis peristiwa gaya pada benda didalam buku komik fisika.

3. Menganalisis peristiwa aksireaksi yang terjadi pada benda didalam buku komik fisika.

4. Melakukan pengamatan tentang pengaruh kelembaman pada benda didalam buku komik fisika.

5. Melakukan pengamatan tentang pengaruh gaya pada benda didalam buku komik fisika.
6. Melakukan pengamatan tentang pengaruh aksi-reaksi pada benda didalam buku komik fisika.

\section{b. Tahap Perancangan (Design)}

Pembuatan instrumen meliputi pembuatan RPP yang mengacu pada silabus, angket validasi para ahli, angket respon, dan angket motivasi belajar siswa. Serta pembuatan lembar validasi yang terdiri dari lembar validasi RPP, lembar validasi materi dan validasi media serta lembar validasi angket respon siswa dan lembar validasi angket motivasi belajar siswa.

Pembuatan buku komik fisika berbasisi konstruktivisme yang akan dikembangkan. Langkah-langkah pembuatan adalah sebagai berikut:

1) Menentukan Ide cerita

Ide cerita dapat berupa tema yang akan di buat cerita. Ide cerita disusun berdasarkan masalah-masalah dalam kehidupan sehari-hari yang pernah dialami siswa secara langsung atau tidak langsung yang berhubungan dengan fisika, serta menentukan tokoh yang akan digunakan dalam cerita.

2) Membuat sinopsis Sinopsis digunakan untuk memberikan gambaran tentang tema atau pokok bahasan pada buku komik. Sinopsis dibuat berdasarkan ide-ide cerita yang dibuat, cerita dibuat untuk mempermudah pembuatan skenario.

3) Membuat skenario

Skenario dibuat berdasarkan sinopsis cerita. Pembuatan skenario bertujuan sebagai petunjuk pelaksanaan operasional.

4) Proses Menggambar dan Komputer

Membuat buku komik dengan menggambar manual dan menggunakan aplikasi photoshop dan CorelDraw, sebelum divalidasi oleh ahli materi dan ahli media. Design awal buku komik fisika berbasis 


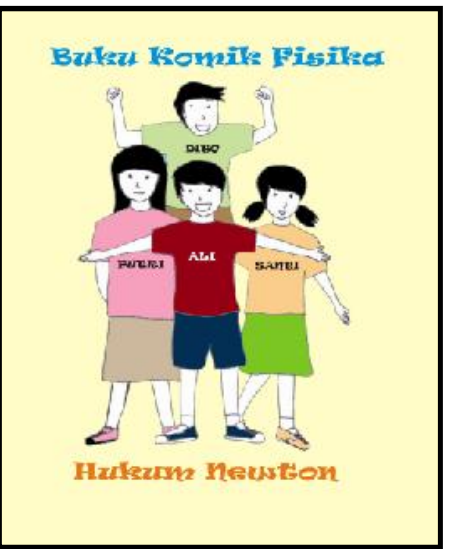

Gambar 2. Design cover sebelum divalidasi

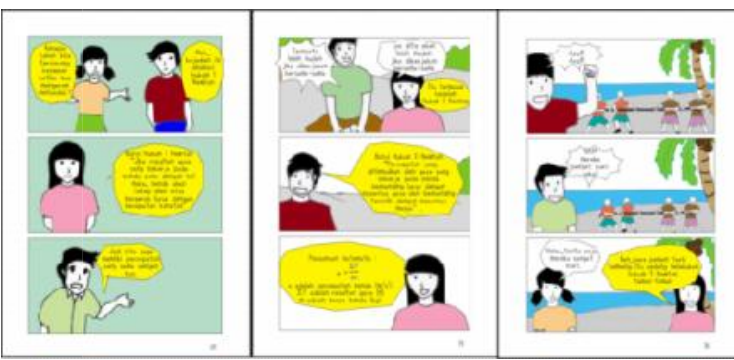

Gambar 3. Design isi buku komik sebelum divalidasi

Buku komik fisika berbasis konstruktivisme yang memiliki karakteristik sebagai berikut:

1. Ukuran buku komik yaitu A5 dan kertas yang digunakan yaitu A4 80 grm.

2. Isi dalam buku komik berupa gambar berwarna yang berbeda dari komik yang warnanya hanya hitam dan putih saja, sehingga buku komik berbasis konstruktivisme lebih menarik untuk dibaca.

3. Cover buku komik berwarna, gambar pada cover sesuai dengan tokoh yang ada di dalam komik.

4. Komik berbentuk buku dan memiliki halaman seperti buku paket pelajaran sehingga berbeda dari komik pada umunya.

5. Buku komik fisika ini berbasis konstruktivisme dimana isi atau ceritanya dapat membangun kembali pengetahuan yang pernah dialami siswa secara langsung atau tidak langsung.
6. Isi atau cerita dalam buku komik berbeda dari komik pada umumnya yang hanya menceritakan tentang kehidupan seseorang, dalam hal persahabatan, cinta, atau pun super hero. Buku komik ini berisikan materi pelajaran fisika yaitu materi yang digunakan adalah hukum newton yang meliputi pengertian gaya, gaya gesek, hukum newton 1, hukum newton 2, dan hukum newton 3 .

7. Kalimat tentang materi hukum newton yang dicantumkan dalam cerita di buku komik akan diberi warna kuning untuk membedakan dengan kalimat biasa, sehingga dapat dipahami bahwa itu termasuk materi yang akan dibahas dalam buku komik. Hasil perancangan awal ini berupa draft I yang siap untuk diuji oleh pakar.

8. Pencetakan dan Penjilidan. Setelah buku komik selesai dibuat dan divalidasi oleh para ahli serta sudah dikatakan layak untuk 
digunakan maka buku komik mulai di cetak dan dijilid sesuai dengan design.

\section{c. Tahap Pengembangan (Develop)}

\section{a. Validasi Ahli}

Karakteristik ahli mencakup pakar dibidang materi dan media. Ahli materi yang dijadikan validator dalam penelitian ini ada tiga orang yaitu satu orang dosen yaitu Erawan Kurniadi, S.Si, M.Pd, dua orang guru mata pelajaran fisika yaitu Agus Supriyadi, S.Pd dan Sarwo Utomo, S.Pd. Serta ahli media yang terdiri dari tiga orang yang ahli dalam bidang pembuatan komik yaitu Teguh Rahayu, Eni Puji Astuti, dan Sista Sulistiyawati. Hasil validasi ahli diperoleh dari angket yang diberikan oleh peneliti kepada validator untuk menilai buku komik yang telah dikembangkan. Keenam validator memberikan penilaian sesuai dengan aspek penilaian yang ada dalam angket. Hasil penilaian validator terhadap materi terlihat pada tabel 1 dan 2 dibawah ini.

Tabel 1. Hasil Validasi Ahli Materi

\begin{tabular}{|c|c|c|c|c|c|c|c|c|c|}
\hline \multirow[t]{2}{*}{ No } & \multirow{2}{*}{\multicolumn{2}{|c|}{$\begin{array}{c}\text { Aspek } \\
\text { Penilaian }\end{array}$}} & \multicolumn{3}{|c|}{ Nilai Validator } & \multirow{3}{*}{$\begin{array}{l}\boldsymbol{\Sigma} \\
\mathbf{X} \\
94\end{array}$} & \multirow{3}{*}{$\begin{array}{c}\begin{array}{c}\mathrm{X} \text { rata- } \\
\text { rata/As- } \\
\text { pek }\end{array} \\
31,33\end{array}$} & \multirow{3}{*}{$\begin{array}{c}\begin{array}{c}\text { Persentase } \\
\text { dari skor } \\
\text { ideal }\end{array} \\
89,52\end{array}$} & \multirow{3}{*}{$\begin{array}{c}\text { Ket } \\
\\
\text { Sang } \\
\text { at } \\
\text { Laya } \\
\text { k }\end{array}$} \\
\hline & & & X1 & $\mathrm{X} 2$ & X3 & & & & \\
\hline \multirow[t]{2}{*}{1} & $\begin{array}{l}\text { Kuali } \\
\text { tas Isi }\end{array}$ & $\begin{array}{l}\text { Ketepat } \\
\text { an }\end{array}$ & 33 & 31 & 30 & & & & \\
\hline & & $\begin{array}{l}\text { Kebaha } \\
\text { saan }\end{array}$ & 13 & 13 & 13 & 39 & 13 & 86,67 & $\begin{array}{c}\text { Sang } \\
\text { at } \\
\text { Laya } \\
\mathrm{k}\end{array}$ \\
\hline \multirow[t]{2}{*}{2} & $\begin{array}{l}\text { Kuali } \\
\text { tas } \\
\text { Instru } \\
\text { ksi- } \\
\text { onal }\end{array}$ & $\begin{array}{l}\text { Dapat } \\
\text { member } \\
\text { ikan } \\
\text { dampak } \\
\text { bagi } \\
\text { siswa }\end{array}$ & 18 & 19 & 17 & 54 & 18 & 90 & $\begin{array}{c}\text { Sang } \\
\text { at } \\
\text { Laya } \\
\mathrm{k}\end{array}$ \\
\hline & & $\begin{array}{l}\text { Dapat } \\
\text { member } \\
\text { ikan } \\
\text { dampak } \\
\text { bagi } \\
\text { guru }\end{array}$ & 4 & 4 & 4 & 12 & 4 & 80,00 & $\begin{array}{c}\text { Laya } \\
\mathrm{k}\end{array}$ \\
\hline \multicolumn{3}{|c|}{ Rata-rata } & & & & $\begin{array}{c}19 \\
9\end{array}$ & 66,33 & 88,44 & $\begin{array}{c}\text { Sang } \\
\text { at } \\
\text { Laya } \\
\mathrm{k} \\
\end{array}$ \\
\hline
\end{tabular}

Tabel 2. Hasil Validasi Ahli Media

\begin{tabular}{|c|c|c|c|c|c|c|c|c|c|}
\hline \multirow[t]{2}{*}{ No } & \multicolumn{2}{|c|}{ Aspek Penilaian } & \multicolumn{3}{|c|}{ Nilai Validator } & \multirow{2}{*}{$\hat{\sum} \frac{i}{x}$} & \multirow{2}{*}{$\frac{\text { dia }}{x / \text { Aspek }}$} & \multirow{2}{*}{$\begin{array}{c}\text { Presentase } \\
\text { Dari Skor } \\
\text { ideal }\end{array}$} & \multirow[t]{2}{*}{ Ket. } \\
\hline & & & $\mathrm{X} 1$ & $\mathrm{X} 2$ & $\mathrm{X} 3$ & & & & \\
\hline \multirow[t]{2}{*}{1.} & $\begin{array}{c}\text { Kualitas } \\
\text { Teknis }\end{array}$ & Keterbacaan & 22 & 24 & 22 & 68 & 13,26 & 90,67 & $\begin{array}{l}\text { Sangat } \\
\text { Layak }\end{array}$ \\
\hline & & $\begin{array}{l}\text { kualitas } \\
\text { Tampilan }\end{array}$ & 47 & 45 & 45 & 137 & 13,7 & 91,33 & $\begin{array}{l}\text { Sangat } \\
\text { Layak }\end{array}$ \\
\hline
\end{tabular}


Tabel 2 di atas memperlihatkan bahwa secara keseluruhan penilaian terhadap kelayakan media produk pengembangan mendapat nilai sangat layak dengan nilai 9,11 $\%$ dengan aspek kualitas teknis yaitu keterbacaan dan kualitas tampilan.

Secara umum penilaian dari hasil uji pakar terhadap produk pengembangan oleh ketiga validator menunjukkan rata-rata skor sebesar 88,44\% untuk ahli materi dan ahli media $91,11 \%$, yang artinya secara keseluruhan buku komik fisika yang dikembangkan mendapat kategori "sangat layak".

\section{b. Uji Kelas Kecil}

Respon siswa kelas kecil yang diperlihatkan tabel diatas menunjukkan bahwa semua siswa memberikan respon sangat baik terhadap media buku komik fisika. Data deskriptif yang diperoleh dalam uji kelas kecil berupa tanggapan dari angket terbuka yang berisi komentar atau pun saran dari siswa. Komentar dan saran siswa tersebut, dijadikan peneliti untuk merevisi produk pengembangan agar layak digunakan pada uji coba terbatas.

Data hasil motivasi belajar siswa diambil menggunakan angket sebanyak 20 butir pernyataan. Pengambilan data motivasi belajar siswa dilakukan dua kali, yaitu sebelum siswa menggunakan produk pengembangan dan sesudah siswa menggunakan produk pengembangan. Maka menggunakan acuan g-faktor (N-Gain) untuk melihat perbandingan atau peningkatan hasil motivasi belajar siswa antara sebelum dan sesudah. Hasil perbandingan antara nilai motivasi belajar siswa sebelum dan sesudah diberi perlakuan dapat dilihat pada tabel 3 . Tabel ini memperlihatkan bahwa peningkatkan motivasi belajar siswa sebelum dan sesudah menggunakan buku komik fisika memiliki NGain sebesar 0,70. Peningkatan motivasi belajar siswa sebanyak $70 \%$ ini mengindikasikan bahwa buku komik fisika berkategori tinggi. Dari 6 siswa uji coba kelas kecil ada 2 anak berkategori N-Gain sedang dan 4 anak berkategori N-Gain tinggi. Melalui buku komik fisika berbasis konstruktivisme ini dapat memberikan kemudahan pada siswa untuk mempelajari materi fisika yang diapliasikan dalam kehidupan sehari-hari siswa.

Tabel 3. Data Motivasi Belajar Siswa Kelas Kecil

\begin{tabular}{lccccc}
\hline \multirow{2}{*}{ No. } & Nama & \multicolumn{2}{c}{ Motivasi } & \multirow{2}{*}{ N-Gain } & \multirow{2}{*}{ Kriteria } \\
\cline { 3 - 4 } & & Sebelum & Sesudah & & \\
\hline $\mathbf{1}$ & Responden 1 & 46 & 84 & 0,70 & Tinggi \\
\hline $\mathbf{2}$ & Responden 2 & 42 & 78 & 0,62 & Sedang \\
\hline $\mathbf{3}$ & Responden 3 & 48 & 85 & 0,71 & Tinggi \\
\hline $\mathbf{4}$ & Responden 4 & 49 & 92 & 0,84 & Tinggi \\
\hline $\mathbf{5}$ & Responden 5 & 67 & 87 & 0,61 & Sedang \\
\hline $\mathbf{6}$ & Responden 6 & 59 & 89 & 0,73 & Tinggi \\
\hline Rata-rata & 51,83 & 85,83 & 0,70 & Tinggi \\
\hline
\end{tabular}

\section{c. Uji Coba Terbatas}

Subjek yang dijadikan uji coba terbatas adalah 22 siswa kelas VIII D SMPN 1 Kecamatan Sampung. Data yang diambil dalam uji coba terbatas ini adalah data berupa respon siswa dan angket motivasi belajar siswa Data respon siswa diambil menggunakan angket dengan jumlah 15 butir pernyataan. Angket yang dibuat memuat aspek penilaian yaitu manfaat, kemenarikan, dan isi. Hasil pengisian angket dilakukan oleh siswa setelah proses uji coba terbatas dilakukan. Penilaian angket ini menggunakan penilaian acuan prosentase yang kemudian diinterpretasikan untuk mengetahui tanggapan setelah dilakukan uji coba. Berdasarkan hasil respon siswa pada kelas uji coba terbatas menunjukkan bahwa seluruh siswa memeperoleh kriteria sangat baik dan rata-rata yang diperoleh sebesar $92,48 \%$ yang berkatagori "sangat baik".

Pengambilan data angket motivasi belajar siswa dilakukan sama seperti pada uji coba kelas kecil yaitu pengambilan data sebelum dan sesudah dengan mengunakan $\mathrm{N}$ Gain. Data angket motivasi belajar siswa terdapat 8 siswa memiliki $\mathrm{N}$-gain sedang sedangkan 14 siswa memiliki N-gain tinggi setelah menggunakan buku komik fisika. peningkatan motivasi belajar siswa sebelum dan sesudah menggunakan buku komik fisika, memiliki N-Gain sebesar 0,67 yang artinya peningkatan motivasi belajar siswa tergolong sedang. 


\section{Tahap Penyebaran (disseminate)}

Pada tahap desseminate (penyebaran), dilakukan penularan produk dengan cara mempublikasikan produk yang dikembangkan ke kelas lain. Selain mempublikasikan, dilakukan penyebaran lembar respon kepada siswa agar dapat mengetahui respon siswa terhadap media yang dikembangkan.

Pengembangan media pembelajaran berupa buku komik fisika berbasis konstruktivisme pokok bahasan newton merupakan serangkaian kegiatan dan proses untuk menghasilkan media pembelajaran fisika yang menarik. Produk yang dihasilkan telah mengalami beberapa perbaikan sesuai saran dari para ahli materi dan media, yaitu pembenahan materi yang diaplikasikan dalam gambar, pembenahan cover, dan pembenahan kalimat dalam buku komik fisika. Tahap tahap pengembangan yang digunakan dalam penyusunan buku komik fisika yaitu, tahap pendefinisian, tahap perancangan, tahap pengembangan, dan tahap penyebaran. Buku komik fisika yang dikembangkan berupa media cetak tokoh yang digunakan dalam buku komik ini adalah doraemon. Isi dalam buku komik berupa gambar berwarna, sehingga buku komik lebih menarik untuk dibaca, cover buku komik berwarna, gambar pada cover sesuai dengan tokoh yang ada di dalam komik, buku komik fisika ini berbasis konstruktivisme dimana isi atau ceritanya dapat membangun kembali pengetahuan yang pernah dialami siswa secara langsung atau tidak langsung yang berisikan materi pelajaran hukum newton yang meliputi pengertian gaya, gaya gesek, hukum newton 1, hukum newton 2, dan hukum newton 3, serta kalimat tentang materi hukum newton diberi warna kuning untuk membedakan dengan kalimat biasa.

Buku komik fisika berbasis konstruktivisme ini berbeda dari komik pada umumnya, karena buku komik fisika ini menyajikan materi yang dikaitkan dalam contoh kehidupan sehari-hari yang pernah dialami atau dilihat siswa, sehingga siswa akan lebih mudah memahami materi fisika. Pengembangan buku komik fisika ini bertujuan untuk menguji kelayakan, respon siswa, dan peningkatan motivasi belajar siswa terhadap produk yang dikembangkan. Hasil kelayakan dari ahli materi memperoleh presentase sebesar $88,44 \%$, ahli media memperoleh presentase sebesar 91,11\%. Hasil dari angket respon siswa pada uji coba terbatas memperoleh presentase sebesar 92,48\%, sedangkan peningkatan motivasi belajar siswa pada kelas uji coba terbatas memperoleh presentase sebesar $0,67 \%$ yang melebihi presentase target peneliti sebesar $0,5 \%$. Berdasarkan presentase tersebut, maka dapat dikatakan bahwa buku komik fisika yang dibuat layak untuk digunakan dalam proses belajar pembelajaran.

\section{KESIMPULAN}

Hasil penelitian pengembangan buku komik fisika pokok bahasan hukum newton berbasis konstruktivisme untuk meningkatkan motivasi belajar siswa menggunakan adaptasi model pengembangan prosedural menurut sugiyono dan model pengembangan 4-D menurut Tiagarajan, Semmel dan Semmel diperoleh simpulan sebagai berikut:

1. Langkah-langkah pembuatan buku komik fisika dalam penelitian ini yaitu analisis ujung depan, analisis siswa, analisis materi, menentukan format, perancangan, validasi ahli, uji kelas kecil dan uji coba terbatas.

2. Hasil penilaian yang dilakukan oleh validator terhadap produk pengembangan didapatkan hasil yaitu presentase ahli materi sebesar $88,44 \%$ dengan interprestasi sangat layak, presentasi ahli media sebesar $91,11 \%$ dengan interprestasi sangat layak, serta hasil respon siswa pada kelas kecil diperoleh presentase sebesar 97,78\% dengan interprestasi sangat layak dan pada uji coba terbatas diperoleh presentase sebesar $92,48 \%$ dengan interprestasi sangat layak. Hal ini menunjukkan bahwa produk pengembangan mempunyai kualitas "baik", dilihat dari respon siswa pada uji kelas kecil dan coba terbatas.

3. Hasil motivasi belajar siswa ketika dilakukan uji kelas kecil memperlihatkan peningkatan tinggi, terlihat dari rata-rata $\mathrm{N}$-Gain yang didapat yaitu sebesar 0,70. Sedangkan pada uji coba terbatas diperoleh $\mathrm{N}$ Gain motivasi belajar siswa sebesar 0,67 dengan kriteria sedang. Hal ini menunjukkan bahwa produk yang 
dikembangakn mampu meningkatkan motivasi belajar siswa.

\section{DAFTAR PUSTAKA}

Arsyad, A. (2014). Media Pembelajaran. Jakarta: PT RajaGrafindo Persada.

Daryanto. (2010). Media Pembelajaran: Peranannya Sangat Penting dalam Mencapai Tujuan Pembeljaran. Yogyakarta: Gava Media.

Dimyati dan Mudjiono. (2009). Belajar dan Pembelajaran. Jakarta: Rineka Cipta.

Listiyani, I.M. dan Ani Widiyati (2012). Pengembangan Komik Sebagai Media Pembelajaran Akuntansi pada Kompetensi Dasar Persamaan Dasar Akuntansi untuk Siswa SMA Kelas XI. Universitas Yogyakarta, 10 (02):80-94.

Rohman, M. dan Sofan Amri. 2013. Strategi \& Desain Pengembangan Sistem Pembelajaran. Jakarta: Prestasi Pustakarya.

Sugiono. 2010. Metode Penelitian Pendidikan. Bandung: Alvabeta. 